\title{
El arte como conciencia de la desolación. Dictadura y destino latinoamericano $^{* *}$
}

\author{
Art as awareness of desolation. \\ Latin American dictatorship and destination \\ A arte como consciência da desolação. \\ Ditadura e destino latino-americano
}

\footnotetext{
* Profesor Titular de la Licenciatura en Español y Literatura, Facultad de Ciencias de la Educación, Universidad Tecnológica de Pereira. Magíster en Literatura Hispanoamericana, Instituto Caro y Cuervo. Formación Especializada en Docencia en Historia y Cultura de América Latina, Universidad Pablo de Olavide, Sevilla, España y el Colegio de América. Actualmente realiza el Doctorado en Literatura en la Universidad Tecnológica de Pereira, Colombia, y el Doctorado en Letras en la Universidad de Buenos Aires, Argentina. Ha publicado libros de ensayo, poesía, cuento y artículos en revistas especializadas. Premio Estímulos del Ministerio de Cultura (2010,2014). Mención de honor III Convocatoria del Concurso "Letras de Pereira para el mundo" (2014), Ediciones sin Nombre, México. Finalista en Poesía, Porfirio Barba Jacob (2004), y Short Story, Letras de Oro, de la Universidad de Miami (1991). Correo electrónico: william@utp.edu.co

${ }^{*}$ Este artículo se origina en el Proyecto de Investigación Ernesto Sábato, una vida entre el ensayo, la ficcióny la pintura, espacios ideológicos de confrontación intelectual y política, inscrito con el código 4-16-6 en el Banco de Proyectos de la Vicerrectoría de Investigacioes, Innovación y Extensión de la Universidad Tecnológica de Pereira, y avalado por par de Colciencias Convocatoria Interna para Proyectos de Investigación año 2015. Este proyecto hace parte de la Línea de Investigación Ernesto Sábato o el arte como conciencia de la desolación. Entre la Utopía y la Distopía en su escritura ensayística y de ficción, línea que pertenece al Grupo de Investigación Crítica y Creación que viene realizando sus actividades académicas desde enero de 2011 y cuyo código de registro en el Gruplac de Colciencias es COL0147392. Artículo de investigación recibido el 15/09/2015 y aceptado el 26/10/2015.
} 


\section{Cómo citar}

MARÍN OSORIO, W. (2015). El arte como conciencia de la desolación. Dictadura y destino latinoamericano. Revista CS, no. 17, pp. 17-38. Cali, Colombia: Facultad de Derecho y Ciencias Sociales, Universidad Icesi.

DOI: http://dx.doi.org/10.18046/recs.i17.2055 


\section{Resumen}

Abstract

Resumo

Ante la insistencia del mal, la literatura se constituye en discurso sobrecogedor que permea críticamente los diversos diálogos que circulan en la sociedad, adquiriendo, más allá de su naturaleza estética, una dimensión política como forma de la reparación de la conciencia y liberación del ser frente a las turbulencias sociales. Y ante los totalitarismos de izquierda y de derecha en los que las palabras desaparecidos y tortura adquieren un sentido político, definiendo a su vez los contornos de un nuevo Leviatán, la democracia sigue siendo el sistema de gobierno que permite el desarrollo de la libertad del hombre. En esta doble perspectiva, surge en nuestra reflexión la figura de un Ernesto Sabato humanista, en sus ensayos y en sus novelas, quien cree en la democracia como sistema político en donde es posible que la criatura humana logre desarrollar sus potencialidades creadoras y adquiera la categoría de persona. Con el informe Nunca Más o Informe Sabato, se cristalizan en 50.000 páginas la denuncia que de la condición humana hiciera el creador de ficciones en su Informe sobre ciegos. En sendos informes se nos revela la exploración que hace el artista del problema del mal-que se constituye en el gran proyecto ético y estético del artista como vidente en la perspectiva de la búsqueda de la identidad del hombre argentino-, y de allí surge un Sabato político y esteta que logra definir muy bien su esencia como artista y como hombre de acción. En dichos textos surgen los avatares del hombre latinoamericano desde la historia escondida, desde el dolor y las voces de la marginalidad.

PALABRAS CLAVE:

Arte | dictadura, | ficción | política | democracia | Latinoamérica

At the insistence of evil, literature constitutes overwhelming discourse that permeates critically the various dialogues that circulate in society, acquiring, beyond its aesthetic nature, a political dimension as a way of repairing consciousness and liberation of front to social unrest. And to the totalitarianism of the left and right in which the words missing and torture acquire a political meaning, in turn defining the contours of a new Leviathan, democracy is still the system of government that allows the development of human freedom. In this double perspective, in our thinking arises the figure of Ernesto Sabato humanist, in his essays and in his novels, who believes in democracy as a political system where it is possible that the human creature is able to develop their creative potential and acquire the category of person. 
With the report Never Again or Report Sabato, crystallized in 50,00o pages the denunciation of the human condition that make the creator of fictions in his Report on blind. In both reports reveals the exploration that artist does about the problem of evil-which constitutes the great ethical and aesthetic project of the artist as seer in the perspective of the search for identity Argentine man, and there comes an esthete and politician Sabato who achieves clearly define his essence as an artist and as a man of action. In these texts emerge the avatars of Latin American man from the hidden history, from the pain and the voices of marginality.

\section{KEYWORDS:}

Art | dictatorship | fiction | politics | democracy | Latin American

Diante da insistência do mal, A literatura se constitui em discurso surpreendente que permeia criticamente os diversos diálogos que circulam na sociedade, adquirindo, muito além de sua natureza estética, uma dimensão política como forma da reparação da consciência e liberação do ser diante das turbulências sociais. E perante os totalitarismos de esquerda e direita onde as palavras desaparecidos e tortura adquirem um sentido político, definindo por sua vez os contornos de um novo Leviatã, a democracia continua sendo o sistema de governo que permite o desenvolvimento da liberdade do homem. Nesta dupla perspectiva, surge em nossa reflexão a figura de um Ernesto Sábato humanista, em seus ensaios e em suas novelas, que acredita na democracia como sistema político onde é possível que a criatura humana consiga desenvolver suas potencialidades criadoras e adquira a categoria de pessoa. Com o relatório Nunca Mais ou Relatório Sábato, se cristalizam em 50.000 páginas a denúncia que da condição humana o criador de ficções fizesse em seu Relatório sobre cegos. Em dois relatórios nos revela a exploração que o artista faz do problema do mal - que se constitui no grande projeto ético e estético do artista como vidente na perspectiva da busca da identidade do homem argentino-, e dali surge um Sábato político e esteta que consegue definir muito bem a sua essência como artista e como homem de ação. Nestes textos surgem os avatares do homem latino-americano a partir da história escondida, desde a dor e das vozes da marginalidade.

\section{PALAVRAS CHAVES:}

Arte | ditadur | ficção | política | democracia | América Latina 
"La lucha del hombre contra el poder es la lucha de la memoria contra el olvido"

MILAN KUNDERA. El libro de la risa y el olvido

\section{Liminar}

Dos ideas generan la escritura de este texto. Una: ante la insistencia del mal, la literatura ha constituido diálogos y monólogos sobrecogedores que han permeado críticamente las diversas capas de la sociedad y sus discursos; de este modo, la palabra dialógica o bivocal -al decir de Bajtín- formulada desde la literatura, ha adquirido, más allá de su naturaleza estética, una dimensión política como forma de reparación de la conciencia y liberación del ser frente a las turbulencias humanas.

La segunda idea de esta argumentación: ante los totalitarismos de izquierda y de derecha en los que las palabras desaparecidos y tortura adquieren un sentido político y definen los contornos de un nuevo Leviatán, la democracia sigue siendo el sistema de gobierno que permite el desarrollo de la libertad del hombree.

En esta doble perspectiva, surge en nuestra reflexión la figura de un Ernesto Sabato humanista. En sus ensayos y novelas expresa su convicción de que la democracia es el sistema político en donde es posible que la criatura humana logre desarrollar sus potencialidades creadoras y adquiera la categoría de persona. El informe Nunca Más o Informe Sabato, cristaliza la denuncia de la condición humana que hiciera el creador de ficciones en su Informe sobre ciegos. En sendos informes se nos revela la exploración que hace el artista del problema del mal -que se constituye en el gran proyecto ético y estético del artista como vidente en la búsqueda de la identidad del hombre argentino-; de allí surge un Sabato político que logra definir muy bien su esencia como artista y como hombre de acción. En estos textos surgen también los avatares del hombre latinoamericano desde la historia escondida, desde el dolor y las voces de la marginalidad.

La hipótesis de trabajo que anima las siguientes reflexiones, se funda en una mirada crítica sobre el tema del mal como aspecto constitutivo de la condición humana. Pensadores y artistas de todos los tiempos han recreado en sus obras esta fundamental reflexión sobre el mal en la naturaleza humana. Dante, Shakespeare, Baudelaire, Dostoievski, Poe, Camus, por citar solo algunos nombres de la literatura universal, nos han entregado a través de su genio la más desgarradora visión sobre lo humano. En esta perspectiva, situamos a un Ernesto Sabato escritor de ficciones (El túnel, 1948; Sobre héroes y tumbas, 1961; Abaddón el exterminador, 1974), e innumerables ensayos sobre la condición humana de nuestro tiempo (El escritory sus fantasmas, 1963, 1970; Apologíasy rechazos, 1979; Uno y el universo, 1970, 1981; La resistencia , 2000; Antes del fin, 1999). La integridad del artista 
proyecta su fuerza interpretativa del mundo en personajes como Juan Pablo Castel, el pintor que mató a María Iribarne, en El túnel; o como Fernando Vidal Olmos, un oscuro hombre que investiga el mundo subterráneo y que deja su testimonio en un Informe sobre ciegos que Sabato integra a su novela Sobre héroes y tumbas. El Informe es una indagación sobre el alma humana que nos recuerda a El hombre del subsuelo de Dostoievski, novela también conocida como Memorias del subsuelo.

En el informe Nunca más (1987) -cuyo prólogo no lleva el nombre del afamado escritor argentino, situación que ha generado cierta polémica entre quienes desvirtúan que el informe haya llevado la firma del escritor y entre quienes insisten en que sí existía, polémica finalmente resuelta por Eudeba, la editorial universitaria de la Universidad de Buenos Aires-el intelectual asume el mismo compromiso de Fernando Vidal Olmos al dirigir una investigación sobre los crímenes cometidos en la época de la dictadura militar. El 15 de diciembre de 1983, el presidente Raúl Alfonsín creó la Comisión Nacional Sobre la Desaparición de Personas (CONADEP), encabezada por el escritor Ernesto Sabato e integrada por René Favaloro, Carlos T. Gattinoni, Ricardo Colombres, Hilario Fernández Long, Gregorio Klimovsky, Eduardo Rabossi, Marshall Meyer, Jaime de Nevares, Hugo Diógenes Piucill, Magdalena Ruiz Guiñazú, Horacio Hugo Huarte y Santiago Marcelino López.

\section{A modo de proemio}

En Calidoscopio, cuento del célebre libro El hombre ilustrado (2002) de Ray Bradbury, un grupo de astronautas son expulsados al espacio luego de que su cohete recibiera un impacto que lo hizo explotar "en un millón de fragmentos". En un mar oscuro, los astronautas hacen un extraño diálogo alrededor de temas cotidianos. La infinita caída libre los comunica, a pesar de todo: ahora sí tienen tiempo para hablar, para encontrarse y reconocerse en ese intercambio inesperado de palabras que produce el accidente espacial. Bromean, hablan de sus secretas pasiones, de sus envidias, del dinero, de las mujeres. El cuento termina con la caída a tierra de una luz blanca que cruza el polvoriento cielo de Illinois, como una estrella fugaz, ante el asombro de un niño y su madre. Algo similar ocurre en el prólogo del mismo libro; Bradbury dibuja a un hombre que tras quitarse la camisa ante un desconocido le narra lo que le sucedió a su piel, y le revela cómo conoció a la bruja que le ilustró el cuerpo: las hermosas y extrañas ilustraciones se movían permanentemente por toda su piel. Las visiones de esas formas y paisajes que habitaban aquel cuerpo, contaban historias a través de voces y pensamientos. Y se asemejaban a cuadros o a invaluables obras de arte. Esa piel era una hermosa galería de imágenes que invitaban a construir un nuevo orden humano. 
El hombre ilustrado volvió hacia mí la cabeza, mostrándome el pecho.

-¿Están todavía ahí? - me preguntó. Durante unos instantes no respiré.

-Si - dije-, están todavía ahí. Las ilustraciones.

- Me cierro la camisa a causa de los niños - dijo el hombre abriendo los ojos-. Me siguen por el campo. Todo el mundo quiere ver las imágenes, y sin embargo nadie quiere verlas.

El hombre se sacó la camisa y la apretó entre las manos. Tenía el pecho cubierto de ilustraciones, desde el anillo azul, tatuado alrededor del cuello, hasta la línea de la cintura.

-Y así en todas partes - me dijo adivinándome el pensamiento-. Estoy totalmente tatuado. Mire. Abrió la mano. En la mano se veía una rosa recién cortada, con unas gotas de agua cristalina entre los suaves pétalos rojizos. Extendí la mano para tocarla, pero era solo una ilustración.

En cuanto al resto, no sé cómo pude quedarme quieto y mirar. El hombre ilustrado era una acumulación de cohetes, y fuentes, y personas, dibujados y coloreados con tanta minuciosidad que uno creía oír las voces y los murmullos apagados de las multitudes que habitaban su cuerpo. Cuando la carne se estremecía, las manitas rosadas gesticulaban, los labios menudos se movían, en los ojitos verdes y dorados se cerraban los párpados.

Había prados amarillos y ríos azules, y montañas y estrellas y soles y planetas, extendidos por el pecho del hombre ilustrado como una vía láctea. Las gentes se dividían en veinte o más grupos, instalados en los brazos, los hombros, las espaldas, los costados, las muñecas y la parte alta del vientre. Se los veía en bosques de vello, escondidos en una constelación de pecas, o hundidos en las cavernas de las axilas, con ojos resplandecientes como diamantes. Cada grupo parecía dedicado a su propia actividad; cada grupo era toda una galería de retratos.

-¡Oh! ¡Son hermosas!-exclamé.

¿Cómo podría describir las ilustraciones? Si en lo mejor de su carrera el Greco hubiese pintado miniaturas, no mayores que tu mano, infinitamente detalladas, con sus colores sulfurosos y sus deformaciones, quizá hubiera utilizado para su arte el cuerpo de este hombre. Los colores ardían en tres dimensiones. Eran como ventanas abiertas a mundos luminosos. Aquí, reunidas en un muro, estaban las más hermosas escenas del universo.

El hombre ilustrado era un museo ambulante. No era ésta la obra de esos ordinarios tatuadores de feria que trabajan con tres colores y un aliento que huele a alcohol. Era el trabajo de un genio; una obra vibrante, clara y hermosa (Bradbury, 2002:4-5).

He querido traer aquí estas preocupaciones de Bradbury, en dos textos suyos que muy bien ilustran el tema que voy a exponer. Por una parte, se revela el drama de la incomunicación del hombre en su vida cotidiana, absorbido como está por otras obsesiones que lo distraen de lo trascendental: los astronautas se percataron de ello en su caída libre. Por otra parte, la visión de los paisajes fascinantes que deberían poblar la 
piel del alma humana. Dos centros alrededor de los cuales girará esta disertación en torno a dos textos: el primero, producto de la ficción, Informe sobre ciegos. El segundo, producto de la historia argentina, Nunca Más o Informe Sabato. Las ficciones tienen sus raíces más profundas en la realidad: la vida del escritor, sus obsesiones, sus fantasmas, los problemas sociales, el conflicto emergente de la libertad del hombre.

\section{Ángeles y demonios}

Sabato escribió el Informe sobre ciegos en un momento convulso de la historia Argentina. Una "noticia preliminar" encabeza la novela: un fragmento de una crónica policial publicada el 28 de junio de 1955 en el periódico La Razón de Buenos Aires. La noticia da a conocer los terribles sucesos del antiguo Mirador, el dormitorio de Alejandra; dormitorio que había cerrado con llave; Alejandra después de asesinar a su padre, le prendió fuego a la habitación:

Esta tragedia, que sacudió a Buenos Aires por el relieve de esa vieja familia argentina, pudo parecer al comienzo la consecuencia de un repentino ataque de locura. Pero ahora un nuevo elemento de juicio ha alterado ese primitivo esquema. Un extraño "Informe sobre ciegos", que Fernando Vidal terminó de escribir la noche misma de su muerte, fue descubierto en el departamento que, con nombre supuesto, ocupaba en Villa Devoto. Es de acuerdo con nuestras referencias, el manuscrito de un paranoico, pero no obstante se dice que de él es posible inferir ciertas interpretaciones que echan luz sobre el crimen y hacen ceder la hipótesis del acto de locura ante una hipótesis más tenebrosa. Si esa inferencia es correcta, también se explicaría por qué Alejandra no se suicidó con una de las dos balas que restaban en la pistola, optando por quemarse viva (Sabato, 1990).

Martín, obsesionado por Alejandra, sabe que ella es la princesa y el dragón, la adolescente terrible, odiada y admirada por hombres y mujeres, quizás más por su temperamento y por su persistente afán en rechazar sistemáticamente todo rastro de mujer en su cuerpo. Fernando Vidal Olmos escribe un relato que culmina con la muerte del propio escritor, una muerte presagiada en el contexto del relato: “¿Cuándo empezó esto que ahora va a terminar con mi asesinato?". Esa narración da cuenta de hechos fundamentales, decididamente unidos al destino del personaje y del escritor. Sabato como artista y ser lúcido que se pregunta por el drama humano en su obra, y un Vidal Olmos que ha capitalizado su experiencia en el mundo de los ciegos, obteniendo dos conclusiones importantes: sus investigaciones son el resultado de sus recuerdos más lúcidos, pero también hay aspectos del inconsciente profundo y vital que era necesario desentrañar en ese informe: la condición humana. Vidal Olmos hace la siguiente reflexión en el capítulo IV de su narración: 
(...) el odio que los ciegos tienen por los videntes es superado por el que tienen a los advenedizos.

¿A qué puede deberse este fenómeno? Al comienzo pensé que podría estar motivado por causas semejantes a las que provoca el rencor entre países vecinos, o entre los propios connacionales; ya se sabe que las guerras más despiadadas son las civiles y bastaría recordar las luchas civiles en la Argentina del siglo pasado o la guerra española. Una maestrita, Norman Gladys Pugliese, a la que utilicé durante algunos meses para estudiar ciertas reacciones de intelectuales de suburbio, pensaba, naturalmente, que el odio y las guerras entre los hombres eran debidos al mutuo desconocimiento y a la ignorancia general; tuve que explicarle que la única forma de mantener la paz entre los seres humanos era mediante la ignorancia recíproca y el desconocimiento, únicas condiciones en que estos bichos son relativamente bondadosos y justicieros, ya que todos somos bastante ecuánimes con relación a las cosas que no nos interesan. Con algunos libros de historia y con la sección policial de los diarios de la tarde en la mano, me veía obligado a explicarle el ABC de la condición humana a esta pobre diabla que se había educado bajo la dirección de distinguidas educadoras y que creía, más o menos, que el alfabetismo resolvería el problema general de la humanidad: momento en que yo le recordaba que el pueblo más alfabetizado del mundo era el que había instaurado los campos de concentración para la tortura en masa y la cremación de judíos y católicos. Con el resultado, casi siempre, de levantarse de la cama, indignada contra mí, en lugar de indignarse con los alemanes: ya que los mitos son más fuertes que los hechos que intentan destruirlos, y el mito de la enseñanza primaria en la Argentina, por disparatado y cómico que parezca, ha resistido y resistirá el ataque de cualquier cantidad de sátiras y demostraciones (Sabato, 1990:259-260).

De este modo, inicia una relación profunda con el mundo de los ciegos, como si ellos estuvieran al cuidado de un reino secreto o hicieran legión o pertenecieran a una cofradía. Vidal Olmos quiere explorar ese universo tenebroso, es un imperativo categórico de su vida, es su deber aunque sienta gran pavor hacia lo desconocido. El mundo subterráneo que quiere explorar, el mundo del subconsciente-como hiciera Dostoievski con sus Memorias del subsuelo-, es una fuerza poderosa que lo presiona a internarse por el mundo oscuro y laberíntico de los ciegos. No es rara esta analogía en un Sabato que tanta admiración manifestó por la obra del autor ruso.

El mundo de los ciegos es un símbolo de las fuerzas oscuras que habitan el alma humana. Un símbolo logrado que inspira terror en cada encrucijada vital por la que atraviesa Vidal Olmos en su investigación de los secretos de un espacio habitado por la desolación y lo desconocido. La novela nos conduce por caminos habitados por la imagen problemática de Alejandra, ser femenino que habita como demonio a Sabato, quien cristaliza en este personaje adolescente la búsqueda de la identidad en un padre violento y misterioso; también nos acerca a Martín, el adolescente escondido en su timi- 
dez que busca absolutos en un universo constreñido por el mal; y Bruno, un intelectual que conoce el pasado de una familia prominente de Buenos Aires.

Una novela, en fin, símbolo de la Argentina de los años 50, de su situación social frente a un pasado en donde la democracia no ha perdurado o no se ha cristalizado como sueño deseable. Más preciso, el informe de Vidal Olmos afirma que su investigación sobre el mundo de los ciegos, el tema del inconsciente, el caos y la oscuridad, empezó en 1947, cuando en la Plaza Mayo, por la Calle San Martín, se encontró de frente con la ciega de la campanilla; lo que significó para él el fin de una etapa de luz y el encuentro con el caos. Como si toda existencia anterior hubiera sido un preámbulo de todo lo que vendría después en el campo de las tinieblas.

\section{La piel del yo}

A Vidal Olmos se le revela que los ciegos son una especie de secta o de organización del mundo del caos que secretamente gobierna el mundo. A partir de ahí, reflexiona sobre el problema del mal, se hace consciente del panorama de desolación, destrucción y muerte que ha generado esta organización en la historia: desde la fundación del capital financiero hasta la manipulación y consumo indiscriminado en la juventud de sustancias psicoactivas que entorpecen las funciones del cerebro; y en donde también caben las inquisiciones y las torturas sistemáticas de los organismos de seguridad del Estado.

Siempre me preocupó el problema del mal, cuando desde chico me ponía al lado de un hormiguero armado de un martillo y empezaba a matar bichos sin ton ni son. El pánico se apoderaba de las sobrevivientes, que corrían en cualquier sentido. Luego echaba agua con la manguera, inundación. Ya me imaginaba las escenas dentro, las obras de emergencia, las corridas, las órdenes y contraórdenes para salvar depósitos de alimentos, huevos, seguridad de reinas, etcétera. Finalmente, con una pala removía todo, abría grandes boquetes, buscaba las cuevas y destruía frenéticamente: catástrofe general. Después me ponía a cavilar sobre el sentido general de la existencia, y a pensar sobre nuestras propias inundaciones y terremotos. Así fui elaborando una serie de teorías, pues la idea de que estuviéramos gobernados por un dios omnipotente, omnisciente y bondadoso me parecía tan contradictoria que ni siquiera creía que se pudiese tomar en serio. Al llegar a la época de la banda de asaltantes había elaborado ya las siguientes posibilidades: $1^{\mathrm{O}}$ Dios no existe. $2^{\mathrm{O}}$ Dios existe y es un canalla. $3^{\circ}$ Dios existe, pero a veces duerme: sus pesadillas son nuestra existencia. $4^{\circ}$ Dios existe, pero tiene accesos de locura. Esos accesos son nuestra existencia. $5^{\circ}$ Dios no es omnipresente, no puede estar en todas partes. A veces está ausente, ¿en otros mundos? ¿En otras cosas? $6^{\circ}$ Dios es un pobre diablo, con un problema demasiado complicado para sus fuerzas. Lucha con la materia como un artista con su obra. Algunas veces, en algún momento logra ser Goya, pero generalmente es un desastre. $7^{\circ}$ Dios fue derrotado antes 
de la Historia por el Príncipe de las Tinieblas. Y derrotado, convertido en presunto diablo, es doblemente desprestigiado, puesto que se le atribuye este universo calamitoso.

Yo no he inventado todas estas posibilidades, aunque por aquel entonces así lo creía; más tarde verifiqué que algunas habían constituido tenaces convicciones de los hombres, sobre todo la hipótesis del Demonio triunfante. Durante más de mil años hombres intrépidos y lúcidos tuvieron que enfrentar la muerte y la tortura por haber desvelado el secreto. Fueron aniquilados y dispersados, ya que, es de suponer, las fuerzas que dominan el mundo no van a detenerse en pequeñeces cuando son capaces de hacer lo que hacen en general. Y así, pobres diablos o genios, fueron por igual atormentados, quemados por la Inquisición, colgados, desollados vivos; pueblos enteros fueron diezmados y dispersados. Desde la China hasta España, las religiones de Estado (cristianos o mazdeístas) limpiaron el mundo de cualquier intento de revelación. Y puede decirse que en cierto modo lograron su objetivo. (...) Mi conclusión es obvia: sigue gobernando el Príncipe de las Tinieblas. Y ese gobierno se hace mediante la Secta Sagrada de los Ciegos. Es tan claro todo que casi me pondría a reñir si no me poseyera el pavor (Sabato, 1990:257-258).

\section{La preparación desde la ficción de una visión apocalíptica del mundo}

Desde sus ensayos y ficciones, Sabato ha hecho un análisis de la condición humana de su tiempo. En Sobre héroes y tumbas señala, en boca de su narrador y refiriéndose a Martín, que "Tenía pavor por los seres humanos: le parecían imprevisibles, pero sobre todo perversos y sucios. Las estatuas, en cambio, le proporcionaban una tranquila felicidad, pertenecían a un mundo ordenado, bello y limpio" (1990:16). Seguramente quienes conocen la trayectoria vital de Ernesto Sabato, sabrán interpretar estas palabras de alguien que viene del universo de la ciencia, y que luego como artista repudiaría en sus ficciones y ensayos. Uno y el universo, es la respuesta desde el arte a la crisis que vivía Sabato como físico en los Laboratorios Curie en Francia. Ésta fue una etapa esencial del escritor, toda vez que conoció a Breton, el animador espiritual del Surrealismo, un movimiento de contracultura que se originó en la crisis moral de la Primera Guerra Mundial, para enfrentar desde el arte, desde las imágenes de los sueños y del secreto lenguaje del inconsciente, la perversión y el desastre. Breton quería que el arte expresara libremente el pensamiento sin la vigilancia de la razón. Sabato atiende a este llamado y será su fiel seguidor, no solo en sus ficciones sino también en sus ensayos sobre nuestro tiempo: el holocausto nazi, el significado de Leonardo Da Vinci y el legado del hombre del Renacimiento, la ciencia como portadora del desastre de una posible hecatombe nuclear, la crisis de la educación, las reflexiones sobre el semitismo y el antisemitismo... 


\section{LA GRAN ILUSIÓN DEL PROGRESO}

El avance de la técnica hizo nacer el dogma del Progreso General e Ilimitado, la doctrina del better-and-bigger. Todo lo que era tinieblas, desde el miedo hasta la peste, iba a ser Iluminado por la Ciencia. No importaba que algunas zonas de la realidad, como lo social, presentaran todavía aspectos desagradables: ya la Razón y los inventos encontrarían la forma de resolver esas dificultades, ya se dominarían las fuerzas de la sociedad como se habían dominado las de la naturaleza.

En el siglo XIX el entusiasmo llegó al colmo: por un lado la electricidad y la máquina a vapor manifestaban el ilimitado poder del hombre; por el otro, la doctrina de Darwin venía a confirmar la idea general del progreso. ¿No éramos superiores al mono? Al Hombre Futuro le esperaba, pues, un porvenir aún más brillante.

(...) El dogma del Progreso fue la fase final del largo proceso de secularización iniciado en Occidente a partir de las Cruzadas: la secularización del propio sentimiento religioso. Porque esto fue una especie de religión laica, hecha a base de moralidad burguesa, de culto por la Razón y la Fraternidad, de creencia en una Humanidad Mejor (Sabato, 1970:185-186).

En el prólogo a Uno y el universo, Sabato expone las razones que lo llevaron a renunciar a la ciencia: el fetichismo científico, la civilización tecnocrática que enajenaba al hombre; inevitable entonces que abrazara con fervor inicial el Surrealismo del poeta Breton, un movimiento que marcó el espíritu atormentado de una época. Sabato había llegado a Bruselas como delegado del Partido Comunista de su país al Congreso contra el Fascismo y la Guerra. Congreso del cual huyó hacia París. Esta experiencia le sirvió como puente para conocer un mundo floreciente cultural y políticamente en la Europa que se preparaba para la Segunda Guerra Mundial.

No imaginaba, por ejemplo, que también por la izquierda se podían llegar a cometer los crímenes que se cometieron en la tiranía stalinista y en las que todavía ahorala imitan; notenía aún suficiente (y amarga) experiencia histórica para admitir que nada vale luchar por la justicia social si no es al propio tiempo unalucha por la libertad del ser humano y por la dignidad que le corresponde. Y en momentos en que con todo el poderío de sus tanques Rusia invade a un pequeño e indefenso país como Checoslovaquia, alguien que grita en defensa del pueblo vietnamita arrasado por la potencia más grande del mundo, no puede sino poner una triste y melancólica marca al lado de los parágrafos que en este libro se dedican a la ilusión soviética (Sabato, 1970:12-13).

Sabato desconfiaba de la ciencia como salvadora del hombre y abrazó con fervor el arte. Uno y el universo es la confesión de esta renuncia -en los planos político y científico-y de su encuentro con la literatura que lo acompañó hasta cuando la ceguera no le permitió escribir más. De ahí que se dedicara a otra pasión, la pintura. Una pintura animada por el espíritu tutelar del noruego Edvard Munch y del neerlandés Vincent Van Gogh uno de sus más amados artistas: pero si para Van Gogh los soles y amarillos en 
espiral eran la obsesión que permeaba sus cuadros, en los de Sabato serán los oscuros violentos de trazos indefinibles; lo que explicaría en parte la oscuridad de su propia alma como creador, un alma atormentada e interesada por expresar la condición del hombre desde el subsuelo en sus obras de ficción. No es de extrañar que en su primera novela, $E l$ túnel, surja la figura del pintor Juan Pablo Castel, y que el padre de Martín en Sobre héroes $y$ tumbas fuese un pintor fracasado del cual se avergonzaba un poco. Castel explicaría también la relación de Sabato con la crítica, una relación problemática, quizás la misma que mantuvo en vida el escritor con la intelectualidad de su tiempo.

Me despierto sobresaltado. Casi he tenido sueños buenos, excepto en estos últimos años, quizás porque mi inconsciencia se fue limpiando con las ficciones. Y la pintura me ha ayudado a liberarme de las últimas tensiones. Probablemente porque es una actividad más sana, porque permite volcar de modo inmediato nuestras pavorosas visiones, sin la mediación de la palabra. Sin embargo, en las telas aún perdura cierta angustia, un universo tenebroso que solo una luz tenue ilumina (Sabato, 1999:74).

En Antes del fin, Sabato suma a muchas de sus reflexiones sobre el destino del hombre, una pequeña carta que le dirigiera entonces Albert Camus, el escritor existencialista, a propósito del conocimiento que tuviera de la novela. Hay una recriminación a Victoria Ocampo por no haber apoyado la publicación de la obra que luego iría a ser celebrada por el argelino y premio nobel francés. Veamos:

El túnel fue rechazado por todas las editoriales del país; hasta por Victoria Ocampo, que se excusó diciéndome: "Estamos medio fundidos, no tenemos un cobre partido por la mitad". Qué auténtica me pareció entonces esa frase de Oscar Wilde: "Hay gente que se preocupa más por el dinero que los pobres: son los ricos”. (...) Finalmente, el préstamo de un generoso amigo, Alfredo Weiss, hizo posible la publicación en Sur, y fue inmediatamente agotada. Al año siguiente, recibí la noticia de su edición francesa, gracias a la generosa iniciativa de Camus.

París, 13 de junio de 1949

Le agradezco su carta y su novela.

Caillois me la hizo leer y me ha gustado mucho la sequedad y la intensidad. He aconsejado a $G a-$ llimard que la editen, y espero que "El túnel" encuentre en Francia el éxito que merece. Hubiera deseado poder decirle todo esto de viva voz, pero la prohibición de una de mis piezas en Buenos Aires me impide dar alli las conferencias previstas. Si, no obstante, llegara a ir a Brasil, trataría de acercarme a título personal a Buenos Aires y me alegraría entonces conocerlo. De aquí a entonces, cuente con toda mi simpatía fraternal.

Albert Camus

(Antes del fin, 1999:100-101) 


\section{El Informe Nunca Más}

Sabato es elegido para presidir una comisión que investigara el fenómeno de la desaparición de personas en la Argentina durante el periodo 1976 y 1981 de la dictadura militar de Jorge Rafael Videla. Tarea de denuncia que el escritor asumió con entereza y valentía, pues documentar los muchísimos casos de torturas y desapariciones de personas y de familias enteras, madres torturadas, niños secuestrados, jóvenes señalados de pertenecer a células subversivas, era una responsabilidad histórica tan grande como sus riesgos. Sabato sentía la presión de los militares involucrados en los procesos y de un sector de la sociedad civil que buscaba perdón y olvido. El escritor recibió amenazas contra su vida y contra su familia.

¿Por qué a un escritor como Ernesto Sabato le fue encomendada una tarea de semejante naturaleza y magnitud? ¿Por qué no a un político o a un funcionario del gobierno?

Sabato publicó la novela Sobre héroes y tumbas en 1961; quizás no imaginó que dos décadas después iba a estar al frente de una investigación semejante en mucho a la inmersión de Fernando Vidal Olmos en las tinieblas y la oscuridad. Dentro de la novela, el Informe sobre ciegos forma un intertexto cultural en tanto representa una ruptura crítica con la decadente sociedad aristocrática argentina de los años 40 y 50, que es el periodo en que se inscribe la narración. Según la nota preliminar, el manuscrito fue encontrado en el apartamento de Vidal Olmos en Villa Devoto; el anónimo cronista afirma que el informe de Olmos explica su comportamiento paranoico, a la vez que plantea otras hipótesis más tenebrosas sobre los hechos.

En el caso de esta novela, y la investigación adelantada por Sabato, se revela un vínculo muy estrecho entre las ficciones y la vida, más allá del imaginario alrededor de la creación literaria, más allá de la puesta en funcionamiento de un artefacto narrativo que crea la ilusión de tener vida propia, de no ser obra de un creador, de un artista, y en donde al parecer no hay relación alguna con la vida misma. Pero al seguir el periplo del escritor y sus reflexiones sobre la condición humana, y volver sistemáticamente sobre el famoso Informe sobre ciegos, no queda la menor duda de una íntima relación entre los intereses del artista y sus posiciones políticas en su obra, pues la obra estética es también una posición política frente a la existencia. Esta perspectiva crítica se ve claramente definida en las siguientes palabras de Käte Hamburguer:

Desde aquí es posible arrojar alguna luz sobre la intromisión del narrador en una ficción. (...) se puede ver ahora que se trata de una relación entre lo ficticio y lo fingido muy distinta estructuralmente de la que guarda con la ficción una narración en primera persona incluida en ella. Cuando la función narrativa de una novela se independiza en forma de yo del narrador o autor lo que sucede es que éste se finge auténtico sujeto enunciativo sin que ello afecte en absoluto a la estructura de ficción de lo narrado. Por así decir, el narrador introduce una pequeña narración en primera persona cuyo héroe es el mismo y que 
permanece al margen de la novela, separadas ambas como aceite y agua. Lo que crea la novela es la función narrativa, no ese yo narrador. El yo del autor que aquí juega consigo mismo nunca pasa a contarse entre los personajes ficticios de su obra. Por el contrario, la narración en primera persona de un personaje de novela sí forma parte del sistema de monólogo y diálogo de la novela, y el poder de la ficción hace ficticia incluso la más extensa y aparentemente autónoma narración en primera persona (La lógica de la literatura, 1995:225).

El conflicto aparente entre la autoría de la novela Sobre héroes y tumbas y el autor interpuesto del Informe sobre ciegos, pone en juego dos instancias narrativas desde la perspectiva del autor real. En el primer caso, el autor real se asume como ser de carne y hueso cuyo nombre aparece registrado en la carátula y el dorso de la portada del libro. El nombre del autor es un paratexto. Él es quien gana los reconocimientos de una sociedad por sus logros intelectuales: Sabato, escritor mundialmente prestigioso, tiene en su haber los premios Cervantes, Menéndez Pelayo, Medici, Rosalía de Castro, Jerusalén, Gabriela Mistral, entre otras importantes condecoraciones de organizaciones internacionales y Doctorados Honoris Causa de diferentes universidades del mundo. En el segundo caso, se problematiza la categoría del autor del texto intercalado, un paréntesis dentro de la historia de Martín, Alejandra y Bruno: el manuscrito de Fernando Vidal Olmos - capítulo tercero de la novela-mencionado en la noticia del periódico La Razón de Buenos Aires, en 1955, seis años antes de la publicación de la primera edición de la novela.

Lo más interesante de este juego intertextual de Sabato, es su dominio de esta técnica narrativa que sitúa a la ficción como referente de la misma realidad. El texto de Vidal Olmos cuestiona al autor real al introducirnos como espectadores del universo tenebroso del inconsciente y el alma humana. El fundamento filosófico de Sabato como presidente de la CONADEP, es el proyecto humanista del movimiento de la modernidad, no en un sentido enciclopédico, sino en el más riguroso sentido originado en el conocimiento de las diferentes pieles que habitan el abismo de esa complejidad que ha sido llamada por los teóricos y los artistas, desde diferentes perspectivas, naturaleza humana.

Esta investigación le permitió al escritor sentir y conocer de primera mano, en un campo distinto a la ficción, ese tenebroso mundo que habita en los hombres, capaces de actos heroicos y sublimes, y a la vez de los más mezquinos y oscuros. El Informe abarcó más de 50 mil páginas que Sabato entregó al presidente Raúl Alfonsín en una rueda prensa, con la presencia de integrantes de su gobierno, de la CONADEP y de la sociedad civil. La investigación sobre la violación de los derechos humanos cubre el periodo entre 1976 y 1983, periodo conocido como Proceso de Reorganización Nacional como se autodenominó la dictadura militar que derrocó al gobierno constitucional de María Estela Martínez de Perón. El Informe Sabato presentó ante la opinión pública los testimonios directos de familiares y amigos de las víctimas, sobre las diferentes modalidades de torturas que habían perpetrado militares contra civiles sospechosos de subversión, en diferentes centros clandestinos de detención de los que se documentaron 340. 
¿Qué abarcó esta investigación? ¿Cuál fue su metodología? ¿A quién investigó? ¿Sobre qué evidencias, si muchos de los cuerpos nunca fueron encontrados, porque fueron arrojados al mar, por ejemplo? ¿A quién acusar en un escenario político de corrupción y amenaza permanente? ¿Cómo salir bien librado de todo ello sin perder su prestigio como intelectual y social demócrata, cuando muchas veces a Sabato se le señalaba como traidor por remover asuntos del pasado de Argentina? Muchos pedían el perdón y el olvido, aunque para otros esa opción tendía un manto de impunidad sobre los crímenes cometidos por los militares.

\section{Luz verde (o "Área Liberada”)}

Queda en claro que cuando la "patota" o "Grupo de Tareas" debía efectuar un operativo, llevaba el permiso de "LUZ VERDE”. De esta manera, si algún vecino o encargado del edificio se ponía en contacto con la seccional de policía más próxima o con el comando radioeléctrico pidiendo su intervención se le informaba que estaban al tanto del mismo pero que no podían actuar.

Para trasponer una jurisdicción policial, las fuerzas operantes debían pedir la "luz verde", lo cual hacían mediante el uso del radiotransmisor, o bien estacionando unos minutos frente a la respectiva comisaría o, incluso, al propio Departamento Central.

Adolfo T. Ocampo (Legajo No 1104) relata del siguiente modo el secuestro de su hija Selma Julia Ocampo:

"A las 2 de la madrugada del 11 de agosto de 1976, penetraron en el edificio y derribaron la puerta del departamento de mi hija y se introdujeron en éste. Otros hombres se quedaron vigilando el departamento. Este episodio fue presenciado desde el departamento de enfrente por el Capitán de Navío Guillermo Andrew quien merced a un llamado telefónico logró que llegaran al lugar dos camiones del Ejército. Los dos grupos se trabaron en un intenso tiroteo (aún hoy puede apreciarse los impactos en el frente). El tiroteo se detuvo cuando las fuerzas recién llegadas a las órdenes del Capitán ya citado pudieron oír a los victimarios gritar: “TENEMOS ZONA LIBERADA”, acorde a esto, se retiraron las fuerzas, dejando actuar a los victimarios, quienes después de destruir y robar, se llevaron a Selma y a una amiga, Inés Nocetti, ambas desaparecidas al día de la fecha...” (Nunca Más, 1984: 19).

Para 1987 Nunca Más llevaba ya 15 ediciones, la edición de ese año no registra el nombre de Sabato. Algunos opinan que originalmente el texto no llevaba la firma del afamado escritor porque él consideraba que el Informe había sido un trabajo colectivo. Sin embargo, en el año 2012 Magdalena Ruiz Guiñazú, quien había sido parte de la CONADEP, denunció censura en el Informe publicado en una nueva edición en el año 2006 por el gobierno de Kirchner, quien reemplazó el Informe elaborado por la Comisión por otro texto escrito por la Secretaría de Derechos Humanos, borrando la firma del escritor. Pero la Editorial Eudeba de la Universidad de Buenos Aires desmintió este 
hecho afirmando que el libro emblemático de los derechos humanos en Argentina había sido publicado en su primera edición de 1984 sin la firma del escritor. La polémica se revivió en septiembre de 2014 cuando, en el marco de una muestra del Nunca Más bajo el gobierno de entonces, Julio César Strassera, el fiscal del juicio a las Juntas Militares, denunció nuevamente que el prólogo del Nunca Más escrito por Ernesto Sabato hubiera sido reemplazado por otra versión de los hechos de los años 70 elaborada por la Secretaría de Derechos Humanos.

Paradójico si se tiene en cuenta que Sabato presidió la comisión y escribió el prólogo, del cual dan fe los demás integrantes de la comisión, prólogo que efectivamente en la edición de Eudeba de 1984 no lleva la firma del escritor, originando la sospecha de que tal vez la censura vino inicialmente del propio gobierno de Raúl Alfonsín. En los registros periodísticos tanto escritos como audiovisuales de la época, podemos apreciar las palabras de Sabato que encontraremos plasmadas en el texto que acompaña como prólogo el Informe Nunca más, reconociendo su particular estilo en la forma de apropiación de la sintaxis y la gramática y su tono existencialista a la manera de Camus. El propio Sabato hace la lectura del texto-prólogo ante Raúl Alfonsín, su comitiva presidencial y ante la Comisión Nacional Sobre la Desaparición de Personas (CONADEP). Podríamos concluir que hay una intención de desaparecer también al escritor, como a tantos compatriotas suyos. Una famosa foto de la época, poco tiempo después del inicio de la dictadura, muestra a Videla, junto a Borges y Sabato, asistiendo a un polémico almuerzo por invitación del propio Videla. Hay incluso declaraciones de estos escritores donde aún no ven con malos ojos el proceso que se iniciaba tras el derrocamiento del Peronismo. Quizá el enemigo común era el Peronismo, y por eso este proceso parecía un augurio de algo nuevo para la Argentina. La historia quizás les dé la razón a los dos famosos escritores, pero la inicial cercanía con el dictador arrojaría una fuerte sombra sobre sus figuras. Circunstancia que les costaría a ambos escritores el Premio Nobel de Literatura. Borges, por su parte, que fue un candidato importante al premio, sería cuestionado por la crítica de su tiempo en su aspiración a tan prestigioso reconocimiento internacional, al ser recibido y condecorado por Pinochet. Sabato, a su vez, se ganó enemistades de todo tipo, y quizás las más decisivas en su trayectoria como escritor, las de carácter intelectual que en la actualidad han pretendido borrarlo de la escena cultural y literaria de su país. La historia de estos escritores pareciera un capítulo más de Las Amistades peligrosas de Choderlos de Laclos, pero en un sentido político; es decir, ellos son de un modo u otro el ejemplo palpable de las peligrosas relaciones entre el artista y el poder político. Pero, a pesar de ello, Borges continúa brillando en la escena cultural no solo de su país, en donde la intelectualidad profesa por su obra un gran respeto, sino también en la historia de la literatura y del pensamiento universales; Umberto Eco, Michel Foucault, Gérard Genette, han hablado con admiración de su obra, entre otras importantes personalidades a nivel mundial. 
Nos queda la obra del escritor Ernesto Sabato, un escritor polémico por sus actuaciones políticas, una obra reconocida por sus méritos literarios; testimonio de ello son los innumerables reconocimientos que recibiera en vida. Destacamos en esta reflexión, igualmente, la valentía del intelectual en su deseo de asumir una posición ética y crítica frente a su tiempo a través de su trabajo artístico y también frente a los crímenes que luego iría a producir el gobierno militar de Videla. Memoria y testimonio de ello son las palabras del prólogo de Nunca Más:

Durante la década del 70 la Argentina fue convulsionada por un terror que provenía tanto desde la extrema derecha como de la extrema izquierda, fenómeno que ha ocurrido en muchos otros países. Así aconteció en Italia, que durante largos años debió sufrir la despiadada acción de las formaciones fascistas, de las Brigada Rojas y de grupos similares. Pero esa nación no abandonó en ningún momento los principios del derecho para combatirlo, y lo hizo con absoluta eficacia, mediante los tribunales ordinarios, ofreciendo a los acusados todas las garantías de la defensa en juicio; y en ocasión del secuestro de Aldo Moro, cuando un miembro de los servicios de seguridad le propuso al general Della Chiesa torturar a un detenido que parecía saber mucho, le respondió con palabras memorables: "Italia puede permitirse perder a Aldo Moro. No, en cambio, implantar la tortura”.

No fue de esta manera en nuestro país: a los delitos de los terroristas, las Fuerzas Armadas respondieron con un terrorismo infinitamente peor que el combatido, porque desde el $24 \mathrm{de}$ marzo de 1976 contaron con el poderío y la impunidad del Estado absoluto, secuestrando, torturando y asesinando a miles de seres humanos. Nuestra Comisión no fue instituida para juzgar, pues para eso están los jueces constitucionales, sino para indagar la suerte de los desaparecidos en el curso de estos años aciagos de la vida nacional. Pero, después de haber recibido varias miles de declaraciones y testimonios, de haber verificado o determinado la existencia de cientos de lugares clandestinos de detención y de acumular más de cincuenta mil páginas documentales, tenemos la certidumbre de que la dictadura militar produjo la más grande tragedia de nuestra historia y la más salvaje. Y, si bien debemos esperar de la justicia la palabra definitiva, no podemos callar ante lo que hemos oído, leído y registrado; todo lo cual va mucho más allá de lo que pueda considerarse como delictivo para alcanzar la tenebrosa categoría de los crímenes de lesa humanidad. Con la técnica de la desaparición y sus consecuencias, todos los principios éticos que las grandes religiones y las más elevadas filosofías erigieron a lo largo de milenios de sufrimientos y calamidades fueron pisoteados y bárbaramente desconocidos (Sabato, 1987: 1-8).

\section{A manera de conclusión}

Este artículo hace un aporte al debate actual sobre el devenir del escritor Ernesto Sabato en el campo de la intelectualidad argentina, un campo que hoy rechaza sistemáticamente al escritor de ficciones por sus posiciones políticas y especialmente por el episodio de 
su breve relación con la dictadura de Videla, a propósito de un almuerzo al que también asistieron como invitados otras prominentes figuras de la vida nacional argentina incluido el propio Borges. En mi reciente visita a Buenos Aires, pude darme cuenta de la dimensión del rechazo a la figura intelectual de Ernesto Sabato por parte de cierto sector de la Academia y de un grupo de escritores. Fui en ese viaje con la ilusión de encontrarme con la ciudad y los lugares emblemáticos por donde transitaban sus seres de ficción, caminé por sus parques y veredas, conversé con un amigo en el legendario Café Tortoni, estuve en el famoso Bar Británico del Barrio San Telmo -en cuyas mesas Sabato escribió su novela Sobre héroes y tumbas, en donde Francis Ford Coppola filmó Tetro y Walter Salles Diarios de Motocicleta, película inspirada en el legendario viaje por Sur América que hicieran el Che Guevara y su amigo Alberto Granado, lugar que fue también frecuentado por Joaquín Sabina y Fito Páez, entre otras importantes personalidades del mundo de la cultura-, y en el Bar Plaza Dorrego en donde Borges y Sabato conversaron largamente sobre la realidad argentina-dos posiciones irreconciliables sobre la realidad nacional-, después de dos décadas de separación y silencio por razones políticas.

El Bar Británico se encuentra en una esquina al frente del Parque Lezama, sitio emblemático de la novela Sobre héroes y tumbas, con su Diosa Ceres al fondo por donde tantas veces transitaron Martín y Sabato en sus cavilaciones sobre el problema general de la existencia. Iba con mis lecturas de adolescente aún en mi memoria y con la ilusión de encontrar los espacios que simbolizaban de algún modo el alma del escritor y que había visto representados en Abaddón el exterminador y en El túnel. Pero regresé a Colombia con el sinsabor de una derrota, la de saber que el escritor admirado en mi adolescencia y juventud era hoy objeto de rechazos sistemáticos por un sector de la intelectualidad argentina. ¿A qué se debía ese rechazo? Pensé que el episodio de Videla podía dar cuenta de ese origen, pero también las posiciones críticas del escritor que no ocultó durante su vida frente a los totalitarismos de izquierda y de derecha que tantas catástrofes produjeron a lo largo de la historia de Occidente durante el siglo XX.

Este artículo pretende ser una aproximación crítica a ese rechazo sistemático del escritor por parte de la intelectualidad argentina. Considero que los escritores tienen derecho a sostener sus posiciones políticas y que su obra estética es de algún modo una forma de asumir también una postura política frente a la realidad. Los escritores también se equivocan. A Sabato no le perdonan quizá ese almuerzo y las declaraciones posteriores que dio a la prensa sobre sus impresiones del recién establecido gobierno militar de Videla. Un gobierno en el que también confiaba Borges, pero que hábilmente no expresó a la prensa en ese momento. Un escritor que fue condecorado por militares y en cuyo pasado familiar también hubo militares a los que cantó en algunos de sus poemas. Un profesor y académico prestigioso me decía que si desaparecía Sabato de la literatura no pasaba nada, pero si desaparecía Borges desaparecía un continente entero, y que tal vez por eso se le perdonaba más a Borges que a Sabato esa relación fugaz con el régimen de la dictadura militar. 
En mi exploración de la situación de la crítica argentina frente a Sabato, encontré unas reflexiones de la escritora Beatriz Sarlo que resultan ser iluminadoras en este proceso de reivindicación de la figura literaria y política del escritor de ficciones que hace parte de mi proyecto de investigación. Sarlo aporta en sus Escenas de la vida posmoderna. Intelectuales, arte y videocultura en la Argentina (1995), especialmente en el Capítulo V. Intelectuales, una serie de ideas que desde mi punto de vista generan un marco de interpretación de la situación del intelectual frente a su tiempo, una posición romántica si se quiere en donde éste se considera a sí mismo la voz de quienes no la poseen o de quienes no han podido acceder a los bienes simbólicos y materiales de la sociedad, y el intelectual como voz privilegiada tiene la plena conciencia de su poder en esa sociedad, un poder originado en el saber. Dice Sarlo, para acompañar el final de este artículo que es, como había señalado más arriba, el inicio de un trabajo mayor en torno a la figura problemática del escritor Ernesto Sabato en el campo de la intelectualidad argentina, y para situar en su justo valor el trabajo del escritor que también asume posiciones vanidosas y arrogantes frente a su tiempo:

Pensaron que estaban en la vanguardia de la sociedad; que eran la voz de quienes no tenían voz. Creyeron que podían representar a quienes vivían agobiados por la pobreza y la ignorancia, sin entender cuáles eran sus verdaderos intereses ni el camino para alcanzarlos. Pensaron que las ideas podían bajar hasta aquellos (los obreros, los campesinos, los marginados) que, sumergidos en un mundo ciego, eran víctimas de su experiencia. Se sintieron portadores de una promesa: obtener los derechos de quienes no tenían ningún derecho. Pensaron que sabían más que el común de la gente y que este saber les otorgaba un solo privilegio; comunicarlo y, si era preciso, imponerlo a mayorías cuya condición social les impedía ver claro y, en consecuencia, obrar en el sentido de sus intereses.

(...) encontraron en sus propios saberes una fuente de poder.

Se organizaron en logias, en clubes, alrededor de revistas, en partidos. Las revoluciones (de izquierda y de derecha) los tuvieron en primera fila: fueron actores protagónicos en los regímenes revolucionarios, tanto que llegaron a convertirse en dirección de las nuevas sociedades surgidas del molde preparado por sus ideas. Estuvieron dispuestos al sacrificio: fueron exiliados, perseguidos, encarcelados, torturados, asesinados, excluidos, censurados, deportados, privados de su nacionalidad, proscriptos. (...) Hubo líderes intelectuales que sospecharon de los intelectuales en general porque no se mostraban perfectamente dispuestos a abandonar perspectivas específicas en función de la tarea histórica que el saber y el poder del saber les había puesto entre las manos. Creyeron entonces que el cambio social es algo que muy pocos pueden dirigir y al que deben plegarse, por la argumentación, la educación o la fuerza, los dirigidos. Se insultaron, se persiguieron, debatieron, ignoraron a otros de su mismo género.

(...) 
Fueron consejeros de príncipes, de dictadores, de autócratas esclarecidos, de otros intelectuales convertidos en políticos, de políticos intelectuales y de políticos que tuvieron poco que ver con el mundo de las ideas.

(...)

Filósofos, moralistas, escritores, artistas: hablaron ante los poderosos sobre el pueblo oprimido; hablaron directamente a los oprimidos para enseñarles el camino que los liberaría de sus cadenas; hablaron entre sí, en una larga conversación que ya lleva siglos, sobre si es bueno hablar con los poderosos, sobre cómo es posible hablar con los oprimidos; sobre qué hay que decir en cada caso. Pensaron que podían dirigirse a la sociedad y pensaron que podían ser escuchados: durante mucho tiempo, fueron escuchados, respetados, consultados (por esa misma razón, también fueron reprimidos). Juzgaron y denunciaron atrocidades; la ideología o la lealtad a viejas lealtades les impidió juzgar y denunciar otras.

\section{(...)}

La lista es interminable y no se puede realizar una suma algebraica que permita decidir si los intelectuales, que encabezan estos capítulos muchas veces luminosos, cometieron más errores que aciertos. En realidad, es absurdo juzgar cualquier práctica humana desde una perspectiva estrechamente contable. Supongamos: como intelectual, Sartre se equivocó más veces que Raymond Aron, y David Viñas más que Ernesto Sabato, Simone de Beauvoir se equivocó menos que Rossana Rossanda, Carlos Fuentes más que Octavio Paz y Godard por lo menos tanto como Luigi Nono. O viceversa. La cuestión no está allí, salvo que se quiera averiguar el balance de una trayectoria individual (la de Sartre o la de Paz) y no de una figura social (Sarlo, 1995:173-186).

El artículo como la investigación que se adelanta, asume una posición crítica de defensa de la integridad de la obra del escritor de ficciones y del ensayista Ernesto Sabato frente a las vicisitudes de su tiempo, teniendo en cuenta que la ficción es una apuesta del escritor por la reflexión en torno al mal como aspecto constitutivo de la condición humana y como elemento estético estructurante de la obra de arte. En suma, después de todas las argumentaciones de la filosofía en torno a la razón instrumental, el proceso de deshumanización de la vida y del arte en nombre del progreso, la racionalización progresiva de Occidente y de cómo ésta provocó todos los desastres que la humanidad conoció a lo largo del siglo XX, pasando por el holocausto de Auschwitz. Y luego de los intentos de comunicación de los artistas de todos los tiempos con seres libres, podemos apreciar que hay aspectos de la condición humana que se deben tener en cuenta en el proceso de análisis de los mecanismos de funcionamiento del mal, no solo como expresión de una ideología, o de una irreconciliable lucha entre clases por el poder político, pues hay móviles más profundos que definen el mal desde el inconsciente mismo, pues la naturaleza humana responde a pulsiones como las 
ambiciones de poder, el crimen, la mezquindad, aspectos éstos representados en la obra de ficción desde el punto de vista composicional como desde la perspectiva de la evaluación ética del mundo (Bajtín).

\section{Referencias}

BAJTíN, M. (2003). Problemas de la poética de Dostoievski. México: Fondo de Cultura Económica.

BRADBURY, R. (2002). El hombre ilustrado. Barcelona: Minotauro.

CHODERLOS DE LACLOS, P. (2008). Amistades peligrosas. Barcelona: Mondadori.

CONADEP (1984). Nunca Más. Informe de la Comisión Nacional sobre la Desaparición de Personas. Buenos Aires: Eudeba.

DOSTOIEVSKI, F. (1983). Memorias del subsuelo. Barcelona: Bruguera.

HAMBURGER, K. (1995). La lógica de la literatura. Madrid: Visor.

KUNDERA, M. (200o). El libro de la risa y el olvido. Barcelona: Seix Barral.

ROSENBLATT, L. (2002). La literatura como exploración. México: Fondo de Cultura Económica.

SABATO, E. (1963). El escritory sus fantasmas. Barcelona: Seix Barral.

SABATO, E. (1970). Uno y el universo. Barcelona: Seix Barral.

SABATO, E. (1979). Apologías y rechazos. Barcelona: Seix Barral.

SABATO, E. (1980). Hombres y engranajes, Heterodoxia. Madrid: Alianza.

SABATO, E. (1989). Entre la letra y la sangre. Bogotá: Planeta.

SABATO, E. (1990). Sobre héroes y tumbas. Barcelona: Seix Barral, 1ª edición 1961.

SABATO, E. (1999). Antes del fin. Barcelona: Seix Barral.

SARLO, B. (1995). Escenas de la vida posmoderna. Intelectuales, arte y videocultura en la Argentina. Buenos Aires: Ariel, Espasa Calpe. 